Section Editor

John J. Millichap, MD

\title{
Teaching NeuroImages: The Charcot shoulder
}

\section{Chiari malformation with syringomyelia associated with arthropathy}

Leonardo F. Bocca, MD

Thiago Y. Tonholo Silva, MD

Benno Ejnisman, MD, $\mathrm{PhD}$

José Luiz Pedroso, MD, $\mathrm{PhD}$

Orlando G. Barsottini, $\mathrm{MD}, \mathrm{PhD}$

Correspondence to

\section{Figure 1 Shoulder radiography shows humeral head destruction (arrow)}

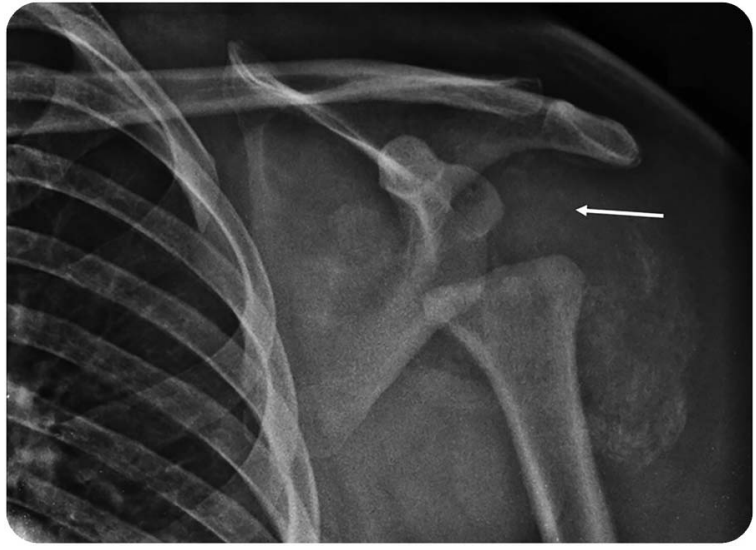

A 39-year-old man presented with 1-year history of shoulder pain, swelling, and limitation of movement. There was a 20-year history of left shoulder and arm numbness. Examination showed decreased vibratory sensitivity on left shoulder, glenohumeral instability, and dislocation. Radiography showed humeral head destruction (figure 1); a spine MRI showed tonsillar herniation and cervical syringomyelia (figure 2). Arthropathy related to syringomyelia was diagnosed.

Chiari type 1 malformation may be associated to syringomyelia, and may cause sensory loss. ${ }^{1}$ Charcot arthropathy is characterized by destruction of the related joint in patients with neurosensory loss. ${ }^{1,2}$ The shoulder may be affected by

\section{Figure 2 Spine MR}
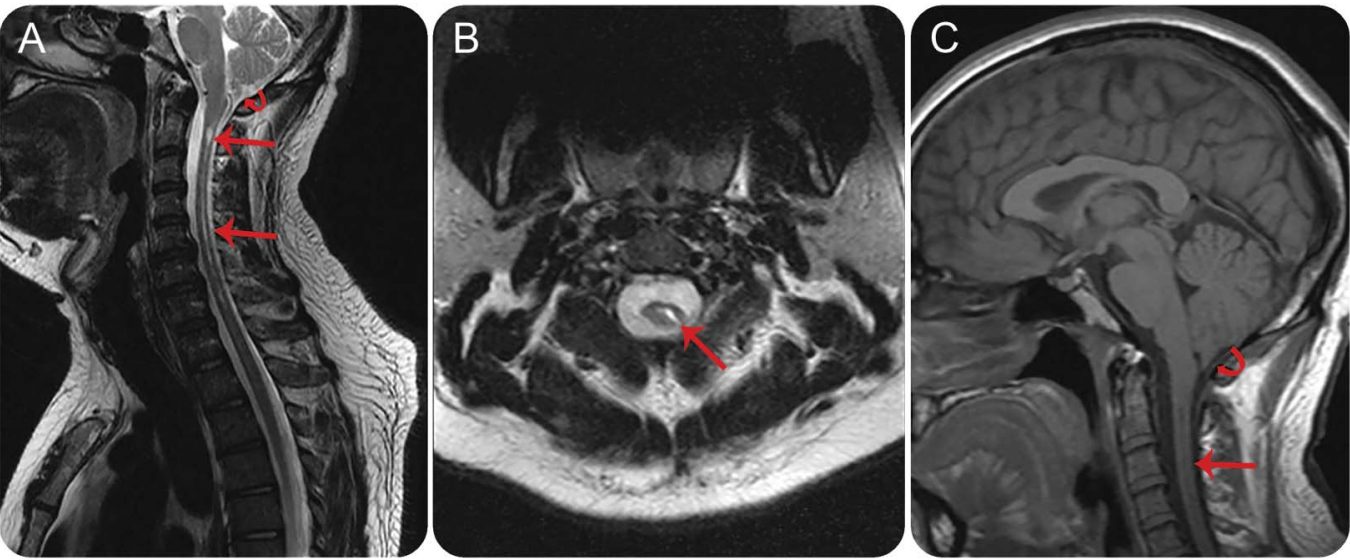

(A) Sagittal T2-weighted spine MRI shows tonsillar herniation (curved arrow) and cervical syringomyelia (straight arrows). (B) Axial T2-weighted spine MRI discloses lateral syringomyelia (left side), the same side of the Charcot shoulder. (C) Sagittal T1-weighted spine MRI shows the Chiari malformation with tonsillar herniation (curved arrow) and syringomyelia.

Download teaching slides: Neurology.org

From the Departments of Neurology and Neurosurgery (L.F.B., T.Y.T.S., J.L.P., O.G.B.) and Orthopedics and Traumatology (B.E.), Universidade Federal de São Paulo, Sao Brazil. 
syringomyelia-induced neuropathy, causing Charcot shoulder. ${ }^{2}$

\section{AUTHOR CONTRIBUTIONS}

Dr. Bocca: case report conception, case report organization, case repor execution, writing of the first draft, manuscript review and critique. Dr. Tonholo Silva: case report conception, case report organization, case report execution, writing of the first draft, manuscript review and critique. Dr. Ejnisman: case report conception, case report organization, case report execution, manuscript review and critique. Dr. Pedroso: case report conception, case report organization, case report execution, manuscript review and critique. Dr. Barsottini: case report conception, case report organization, case report execution, manuscript review and critique.

\section{STUDY FUNDING}

No targeted funding reported.

\section{DISCLOSURE}

The authors report no disclosures relevant to the manuscript. Go to Neurology.org for full disclosures.

\section{REFERENCES}

1. Yanik B, Tuncer S, Seçkin B. Neuropathic arthropathy caused by Arnold-Chiari malformation with syringomyelia. Rheumatol Int 2004;24:238-241.

2. Liu H, Wang Y, Yang Z, Wang K. A case report of Charcot arthropathy caused by syringomyelia and Chiari malformation complicated with scoliosis. BMC Res Notes 2014;7:277. 


\section{Neurology}

\section{Teaching NeuroImages: The Charcot shoulder: Chiari malformation with syringomyelia associated with arthropathy}

Leonardo F. Bocca, Thiago Y. Tonholo Silva, Benno Ejnisman, et al.

Neurology 2017;89;e38-e39

DOI 10.1212/WNL.0000000000004154

\section{This information is current as of July 24, 2017}

\section{Updated Information \& Services \\ Supplementary Material}

References

Subspecialty Collections

Permissions \& Licensing

Reprints including high resolution figures, can be found at:

http://n.neurology.org/content/89/4/e38.full

Supplementary material can be found at:

http://n.neurology.org/content/suppl/2017/07/24/WNL.0000000000004 154.DC1

This article cites 2 articles, 0 of which you can access for free at: http://n.neurology.org/content/89/4/e38.full\#ref-list-1

This article, along with others on similar topics, appears in the following collection(s):

All Clinical Neurology

http://n.neurology.org/cgi/collection/all_clinical_neurology MRI

http://n.neurology.org/cgi/collection/mri

Peripheral neuropathy

http://n.neurology.org/cgi/collection/peripheral_neuropathy

Information about reproducing this article in parts (figures,tables) or in its entirety can be found online at:

http://www.neurology.org/about/about_the_journal\#permissions

Information about ordering reprints can be found online:

http://n.neurology.org/subscribers/advertise

Neurology ${ }^{\circledR}$ is the official journal of the American Academy of Neurology. Published continuously since 1951 , it is now a weekly with 48 issues per year. Copyright @ 2017 American Academy of Neurology. All rights reserved. Print ISSN: 0028-3878. Online ISSN: 1526-632X.

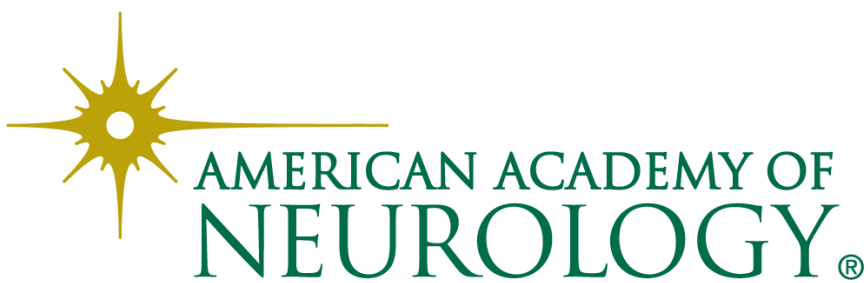

